\title{
Problems and Countermeasures on Personnel Training of Innovation Entrepreneurship in Colleges and Universities
}

\author{
Ronghua Ma \\ College of Finance and Trade, Bohai University, Jinzhou, 121013, China
}

1774532051@qq.com

Keywords: colleges and universities; innovation entrepreneurship; personnel training; problems and countermeasures

\begin{abstract}
In the colleges and universities to carry out innovative entrepreneurship education, and actively encourage college students to start their own businesses, is the education system to learn and practice the scientific concept of development, is a major strategic initiatives to serve the construction of innovative countries. This paper puts forward some suggestions on how to cultivate the innovation and entrepreneurship talents in colleges and universities, such as the form of educational guidance, the separation of innovation education and entrepreneurial education, the lack of innovative teaching methods, the low participation rate of innovative entrepreneurship projects and the lack of qualified teachers and other issues, the countermeasures as follows: to create a good culture atmosphere, to build innovative talents training system, to improve the organization of innovation and entrepreneurship in colleges and universities, to build innovative and innovative education curriculum system, to reform and optimize the teaching mode with innovation and entrepreneurship reform, to construct innovative educational practice platform, and to establish the evaluation mechanism of innovation and entrepreneurship education.
\end{abstract}

\section{Introduction}

Innovation is for the development of needs, the use of known information and conditions, break through the routine, discover or produce a new and unique, and valuable new things and new ideas. The essence of innovation is a break through, that is, breaking the old mindset, the old conventional discipline. The core of the innovation is "new", or the change of the structure of the product, performance and external features, or the creation of design, content forms and means, or the the rich and perfect of content. Entrepreneurship is the process by which entrepreneurs are trying to optimize the integration of resources that they can own, thereby creating greater economic or social values. Entrepreneurship is a kind of labor, is a need for entrepreneurs to operate, organize, and use services, technology, artifacts thinking, reasoning and judging behavior. Innovation and entrepreneurship is based on the entrepreneurial activities on the basis of innovation, which is not only different from the pure innovation, but also different from the pure entrepreneurship. Innovation emphasizes the pioneering and original, while entrepreneurship emphasizes the act of gaining interest through practical action. Therefore, in the concept of innovation and entrepreneurship, innovation is the basis and premise of entrepreneurship, entrepreneurship is the embodiment and extension of innovation.

Innovation and entrepreneurship education is a new mode of training talents in Colleges and universities in the era of knowledge economy, to cultivate students' ability of innovation and entrepreneurship as the goal, to all students as the object of training, making high-quality talents with innovative consciousness and innovative entrepreneurial thinking and innovation ability under the new social norm. China's colleges and universities have been the innovation and entrepreneurship education as an important measure to deepen the reform of education, has formed a positive government advocacy, colleges and universities to promote the broad masses of students take the initiative to participate in the pattern of innovation and entrepreneurship [1]. In the colleges and universities to carry out innovation and entrepreneurship education, and actively encourage college students to start their own businesses, is the education system to learn and practice the 
scientific concept of development, a major strategic initiatives to serve the construction of innovative countries; deepening the teaching reform of higher education and an important way to cultivate students' innovative spirit and Practice ability; is the implementation of entrepreneurship to promote employment, an important measure to promote the full the employment of College graduates. The scientific design and effective implementation of the innovation and entrepreneurship training system is the need of deepening the reform of the educational system in colleges and universities and has become a new trend of modern education reform, to improve the quality of personnel training, improve the domestic and international status, has theoretical and practical significance to realize the goal of education development and so on.

\section{Realistic Meaning on Personnel Training of Innovation Entrepreneurship in Colleges and Universities}

Innovation and entrepreneurship education is called "the third passport" by the United Nations as important as academic education and vocational education. It is not a short-term knowledge and skills education, nor is it a rapid creation of enterprise education. With the creative, innovative and groundbreaking as the connotation, with knowledge and skills education and innovation and entrepreneurship practice as the subject, to cultivate students' innovative entrepreneurial spirit, enhance students' innovative entrepreneurial awareness and thinking, improve students' ability to innovate and innovate entrepreneurial quality, so that students dare to innovation and entrepreneurship, good at innovation and entrepreneurship, innovation and entrepreneurship as the goal of quality education. The practical significance of cultivating talents in colleges and universities is as follows:

(1) The need to build an innovative country. An innovative country is to technological innovation as the core driving force of economic and social development, it mainly shows that the investment in innovation activities is high in the whole society, the international technology of important industry is highly competitive, the performance of input-output is higher, technological innovation plays an important role in industrial development and national wealth growth. In the university to carry out innovation and entrepreneurship education is an important measure to build an innovative country, is an important force to cultivate innovative and entrepreneurial talents. Innovation and entrepreneurship education in colleges and universities through innovation and entrepreneurship theory and innovation and entrepreneurship practice, to enhance college students innovation and entrepreneurship awareness and innovative business thinking, improve innovation and entrepreneurship and comprehensive quality, to encourage students to actively participate in innovation and entrepreneurship, courage to join the social practice, to promote scientific and technological achievements into actual production, and make contribution to the construction of innovative country.

(2) the need to solve the employment problems in Colleges and universities. The reform of economic system and the transformation of labor employment mechanism bring opportunities and challenges to college students' employment. The state government agencies continue to deepen the reform, enterprises continue to carry out structural adjustment, laid-off shunt personnel continue to increase, and the social demand for labor is declining [2]. Under the historical conditions of higher education from elite to popular, there are millions of college graduates need employment every year, if these graduates directly flock to the job market, there will certainly be "graduation on unemployment" situation. In the face of this situation, college students must get rid thinking of "wait, rely on, to", cannot simply flock to the job market, but actively realize self-entrepreneurship. Entrepreneurship not only can promote social employment, but also for social development to provide good intellectual support for the success of scientific and technological achievements for the real productive forces to provide support for the actual productivity.

(3) To meet the challenge of knowledge economy. Knowledge economy is a high-tech industry as the pillar, relying on intellectual resources, taking into account the long-term interests of the sustainable development of the economy. In the era of knowledge economy, knowledge industry is the economic growth mode, the knowledge industry has become the leading industry, and the 
knowledge economy has become the new economic form. Relative to the agricultural economy and industrial economy, knowledge economy is a new economic form based on the production, distribution and consumption of knowledge. Knowledge economy is inseparable from the talent, in particular, cannot be separated from innovative consciousness, innovative ability and innovative personality, seize the opportunity of knowledge economy, the key is to cultivate entrepreneurial talent of innovative ability. This requires China's higher education must deepen the reform, promote the transformation of educational ideas and ways, to cultivate innovative entrepreneurial talents, to seize the opportunity of knowledge economy and meet the challenges of knowledge economy

(4) The need to improve the comprehensive quality of students. Innovative entrepreneurship education aims to cultivate students' thinking flexibility, agility and creativity, and cultivate talented people who can create problems, solve problems, solve problems, and be proactive and pioneering. Innovative entrepreneurship education can improve the overall quality of students, so that in the face of modernization, facing the world, facing the future of the economy open society in an invincible position. Cultivating innovative talents with high quality is an urgent requirement to improve the national competitiveness. With the internationalization of the economy and the development of globalization, the competition in the world is becoming more and more prominent. The competition of the economy is the competition of science and technology. It is directly expressed as the competition of talents. China's current level of talent development and the developed countries, there is still a big gap, to strengthen the innovation and entrepreneurship education in colleges and universities, to support the development of the country to provide the necessary talent.

(5) The need of deepening educational reform. Innovation and entrepreneurship education to adapt to the needs of economic and social development and the development of higher education, the implementation of "deepening education reform to promote quality education" concept of personnel training, contributes to put the concept of education in practice, at the same time, innovation and entrepreneurship practice summary and improvement provides the basis for good relationship between the two complement each other, and jointly promote the reform and improvement of teaching and learning in colleges and universities. Economic and social development has led to the reform of personnel training model, for the development of innovative entrepreneurship education provides an opportunity and rapid development momentum. The employment of college graduates is an important livelihood project in the field of education. Carrying out innovation and entrepreneurship education in Colleges and universities, it is necessary to break down the training mode of traditional education in colleges and universities, pay more attention to the cultivation of talents, and integrate theory and practice, knowledge and creativity, learning and entrepreneurship, directly services for the social and economic development [3].

\section{Problems on Personnel Training of Innovation Entrepreneurship in Colleges and Universities}

China's innovation and entrepreneurship education development is relatively backward compared to foreign countries, many colleges and universities actively explore and achieved some achievements, but there are still many problems to be solved, highlighted in the following aspects:

(1) Educational guidance is in the form [4]. In China, in addition to family education and social impact and other factors, the classroom level of entrepreneurship education basically began in the higher education stage, which exposed the innovation entrepreneurship education is not systematic and inconsistent. In foreign countries, many countries, innovative entrepreneurship education is from the beginning of primary school. China's innovative entrepreneurship education means backward, basically reflected in the classroom teaching, teaching resources update slowly, knowledge lag, and cannot keep up with the times of economic development. Innovation and entrepreneurship practice, not on the field of learning, study or training, but focused on the guidance of the student business plan competition. Innovation and entrepreneurship activities are mostly organized by the community activities, did not play a practical role, and did not form a sustainable development model. 
(2) Separation of innovation education and entrepreneurship education. Although colleges and universities pay more and more attention to innovation and entrepreneurship education, but the separation of innovation education and entrepreneurship education, engineering colleges and universities pay more attention to innovation and neglect of entrepreneurship, students in the laboratory engage in inventions, no contact with entrepreneurship education. Economics and management colleges and universities are focused on entrepreneurship education, ignoring innovation education, such as business Incubation Park, entrepreneurial competition and entrepreneurial lectures, are focused on entrepreneurship education, while ignoring the innovative education. Innovation education and entrepreneurship education are inseparable, only to cultivate students' innovative thinking and innovation consciousness, can improve the effectiveness of entrepreneurship education, college innovation education and entrepreneurship education together, become a holistic and systematic education content.

(3) Lack of innovative teaching methods. Innovation and entrepreneurship should adopt case teaching, flip classroom and social practice and other teaching methods, change of the "spoon" teaching methods the teacher one-way indoctrination knowledge, increase the "theme business" and "risk analysis" and other more participatory courses. But many high-techs and the use of multimedia teaching, but most are limited to play the slide. Teaching methods is based on teaching, theory and practice is also limited to examples, analysis, discussion and homework. Most students cannot experience, participate and operate in a way that leads students to take notes, get out of class notes and exams. Training is "test type" students, analysis of problems and problem-solving ability is poor.

(4) Innovation and entrepreneurship project participation rate is low. Innovation and entrepreneurship projects play an important role in promoting the transformation of educational concepts, students' main body consciousness and innovation consciousness and so on [5]. National colleges and universities and administrative departments, held a large number of innovation and entrepreneurship competition every year, to encourage students to declare innovative business projects. But the enthusiasm of students to participate is not high, the participation rate is low, coverage is narrow. The reason is: teachers to guide or participate in entrepreneurial activities, or incentive measures are not perfect; entrepreneurial competition focus or evaluation points focused on the outstanding and mature projects, that is, the judge of the results, rather than a process assessment mechanism. A number of projects that have just started or are not mature, the competition becomes a burden.

(5) Lack of teachers. Innovative entrepreneurship education involves more knowledge, strongly comprehensive and practical, and teachers should have both high theoretical knowledge and rich entrepreneurial management experience. At present, the teachers engaged in the innovation and entrepreneurship education mainly comes from the administrative departments of the students "employment". Most of the teachers lack the experience of enterprise management and entrepreneurship, and some only accept the short-term training. The lectures content focus on the theoretical analysis and cannot really cultivate the students' entrepreneurial ability and consciousness. Some colleges and universities have appointed entrepreneurs as part-time teachers, but there are serious shortcomings in organizational coordination, financial support and system guarantee. In addition, the entrusted entrepreneurs' lack of practical teaching experience, the teaching effect is difficult to meet the requirements.

\section{Countermeasures on Personnel Training of Innovation Entrepreneurship in Colleges and Universities}

In view of the existing problems in the cultivation of innovative talents in colleges and universities, the countermeasures are as follows:

(1) To create a good atmosphere of innovation and entrepreneurship. To create a free, open and proactive innovation and entrepreneurial atmosphere, to stimulate college student's innovation and entrepreneurship passion and desire, to reduce the ideological and psychological burden is necessary. Make full use of television, network, newspapers and advertising and other media means 
to promote business stories and success stories, promote entrepreneurship policy, to encourage innovation, to allow failure, tolerance failure, the formation of innovative and innovative social and cultural atmosphere. Strengthen the campus innovation and entrepreneurship information service network construction, providing a variety of entrepreneurial projects, entrepreneurial resources and entrepreneurial policies and other information consulting services. Invite entrepreneurs and entrepreneurs to make a report, establish an example and model of innovation and entrepreneurship, and the formation of both advocating science and innovation, both positive and willing to innovate and entrepreneurial cultural atmosphere.

(2) Constructing the training system of innovative talents. The discovery, cultivation and use of innovative talents are a complex social systems engineering. Colleges and universities must create the relaxed environment to respect for the growth of innovative talents, encourage innovation entrepreneurship, make good mechanism for innovative talents as soon as possible, the best use of the talent shows itself to provide a solid guarantee of talent, for the construction of an innovative country. Innovative talent training system mainly involves the following aspects: to establish a student-oriented concept, to cultivate students innovative personality and awareness; to build a student-oriented education model; respect for student personality, the implementation of personalized education; building creative teachers; constructing personalized education system; to create a good campus culture, enrich extracurricular activities of science and technology and society practice.

(3) Improve the organization of innovation entrepreneurship [6]. Constructing innovation and entrepreneurship center in create space and creative workshops and other forms, in accordance with the "creative ideas, creative cultivation, achievement transformation, project packaging, start-up enterprises, marketing, company consulting " process, to provide integrated services for students entrepreneurship; To build innovation and entrepreneurship research institute, to improve the intellectual support for innovation, to strengthen the growth of entrepreneurs and start-ups, new business model, factors of innovation and entrepreneurship, innovation and entrepreneurship success stories and other research, to provide theoretical basis and development guidance; Building innovative technology institutions, help innovative entrepreneurs to assess the prospects for technology; building innovative entrepreneurship practice base for entrepreneurs with entrepreneurial ideas to provide more opportunities to achieve their dreams.

(4) the construction of innovative entrepreneurship education curriculum system. On the basis of students with professional knowledge and skills, the establishment of innovation and entrepreneurship education curriculum system, set up business management, economics and finance and other related courses, a comprehensive knowledge development. Engineering colleges and universities focus on professional skills, should be appropriate to complement the knowledge with humanities and management of economic; economic management institutions because of their own advantages, with entrepreneurial foundation, but the actual operational capacity is insufficient, can set up practical courses to make up. Innovative entrepreneurial curriculum system should also be in line with the professional curriculum system, to achieve complementary results, rather than out of touch or no contact. In the innovation and entrepreneurship teaching, in the professional education as the basis, in the professional education subject background, set up the relevant innovative entrepreneurial curriculum system.

(5) with innovative entrepreneurship reform to optimize the teaching model. To solve the problems of innovation and entrepreneurship education, as the focus of deepening innovation and entrepreneurship education reform, into the personnel training system, enrich the curriculum, innovative teaching methods, strengthen teachers, promote teaching, strengthen scientific research, breakthrough talent training weak links, enhance students' innovative spirit, entrepreneurial awareness and innovative entrepreneurial ability. Optimize the teaching content, strengthen the construction of teaching materials and curriculum rationality; teaching process is not limited to the classroom and teaching materials, and contact to practice, and applied to practice; based on the first classroom, make full use of the second classroom, to carry out the experiment and practice 
activities, in the process of activities to consolidate the knowledge of the first classroom, and carry out the innovation and entrepreneurship education training based on the knowledge [7].

(6) to build innovative entrepreneurship practice platform [8]. Innovative entrepreneurship education not only to master the theoretical knowledge, pay more attention to practical ability, the school should provide students with a variety of practice platform to improve the innovation and entrepreneurship awareness and ability. Innovative entrepreneurial practice includes two parts: innovation practice and entrepreneurial practice. The practice of innovation focuses on cultivating students' innovative spirit and creative thinking, developing the ability of innovative operation; entrepreneurial practice focused on the establishment of entrepreneurial awareness, master the basic skills of entrepreneurship. Innovative practice and entrepreneurial practice emphasize the basic qualities of students, so that students independently find problems and solve problems, to achieve the purpose of thinking and creation. Both have the education object, the goal, the function and the nature and so on, many aspects common, should consider the innovation and entrepreneurship practice to take into account the overall development.

(7) The establishment of innovative entrepreneurship education evaluation mechanism. Innovation and entrepreneurship education has the characteristics of high cost, strong practice and lag of performance. The evaluation mechanism tries to be scientific and diversified. It is necessary to improve the enthusiasm, give reasonable and reasonable judgment, and avoid evaluation of excessive form. The government should set up scientific and reasonable evaluation mechanism according to the type of university, and the experts and scholars involved in the evaluation should have higher theoretical knowledge and rich practical skills. Colleges and universities should also establish evaluation mechanism according to their own characteristics, and strive to combine process and result, quantitative and qualitative, static and dynamic. It not only pays attention to the explicit knowledge, but also emphasizes the evaluation of students' morality, emotion and will. The results of the evaluation should be timely feedback in order to introduce a competition mechanism.

\section{References}

[1] H. T. Chang, "Research on the construction of innovative and entrepreneurial talents training system in Colleges under the background of new normal," China Educational Technology \& Equipment, vol. 30, no. 18, pp. 152-53, 2016.

[2] X. H. Shi, M. Cao, "The influence of innovation and entrepreneurship education on College Students' employability," Intelligence, vol. 16, no. 18, pp. 164-165, 2016.

[3] Y. J. Zhao, "Meanings, Effects and Choices of Cultivating Talents in Universities' Innovation and Startup Education," Journal of Hubei Industrial Polytechnic, vol. 29, no. 5, pp. 31-35, 2016.

[4] Q. Wang, "Problems and countermeasures in the cultivation of innovative talents in Colleges and Universities," Popular Science, vol. 80, no. 6, pp. 114-114, 2016.

[5] Y. J. Zhao, "On the guidance of College Students' innovation and entrepreneurship projects," Science \& Technology Vision, vol. 4, no. 15, pp. 328-329, 2014.

[6] D. N. Qian, Z. X. Zhang, "Education is 4.0 Times the Plight of Creative Talents Training in Colleges and Universities and the Countermeasures," Education Forum, vol. 8, no. 43, pp. 29-30, 2016.

[7] S. Q. Song, "Problems and countermeasures of innovation and entrepreneurship education in Colleges and Universities," Shangqing, vol. 28, no. 40, pp. 222-222, 2016

[8] C. Zhang, H. B. Zhou, F. Y. Luo, "Constructing Integration Practice Platform of Undergraduates' Innovation and Entrepreneurship Education," Research and Exploration in Laboratory, vol. 32, no. 11, pp. 262-265, 2013. 